\title{
閉ループ機構の動力学解析の計算手順*
}

\author{
杉 本 浩 $\cdots * 1$, 松 本 義 雄 ${ }^{* 1}$
}

\section{Computational Scheme for Dynamic Analysis of Closed Loop Mechanisms}

\author{
Koichi SUGIMOTO and Yoshio MATSUMOTO
}

\begin{abstract}
In this paper, derivation of equations for the dynamic analysis of closed loop mechanisms is described. The unified method which is applicable to any types of mechanism is obtained as a result. The condition of non-singular matrix which expresses the equilibrium of forces and moments on links and joints shows that the procedure of the derivation is a kind of conventional loop cut method. However, in this method, the forces and moments at cut points can be described by the explicit functions of the forces and moments acting on the links without introducing extra parameters such as the Lagrange's multiplier. It is also shown that the procedure of the derivation can be expressed by linear functions formed by matrices and vectors which helps to develop a computer program with less cost.
\end{abstract}

Key Words : Robot, Dynamics, Kinematics, Mechanism, Screw Theory, Motor Algebra

\section{1. 緒言}

開ループ機構の動力学解析では, リンクに作用する 力は，そのリンクから開放端にあるリンクに作用する 静的および動的力の合力であり，この合力と対偶を介 して受ける力との釣り合いから，力解析や運動方程式 の導出が容易に行える。これに対し，閉ループを持つ 機構の動力学解析は,ループ内での力の釣り合い条件 から，対偶作用力を求め，これから力解析や運動方程 式の導出を行わなければならない。また閉ループ機構 にはアクチュエータで駆動されない受動対偶が多く存 在し，受動対偶での仮想仕事の条件を，力の釣り合い 式に加えなければならない。このように閉ループ機構 の動力学解析は開ループ機構のそれに比べ非常に複雑 なものとなる。

従来の閉ループ機構の動力学解析ではループの中の 1つの対偶を取り去り,ループを切断した仮想木構造を 考え，ラグランジュ乗数を用いる方法や，機構全体の 仮想仕事の原理から, 力解析や加速度解析を行う手法 が提案されている(1) (3).これに対し筆者はリンクの速 度, 加速度, 力を 6 次元べクトルであるモー夕（スク リュー座標) で表し，力の釣り合い式と，受動対偶の

* 原稿受付 1997 年 7月 15 日.

*1 正員, (株) 日立製作所生産技術研究所(画 244-0817 横浜市 戸塚区吉田町 292).
仮想仕事の条件から,力解析や運動方程式の導出を行 う手法を開発した(6)。この手法では，モー夕を用いる ことにより，閉ループ機構での力の釣り合い式がモー 夕の線形結合で表され，また仮想仕事の条件が2つの モータである6次元ベクトルの双線形形式で表される ため, 線形演算のみで動力学解析を行うことが可能で あり，そのためラグランジュ乗数のような新たなパラ メー夕を導入することなしに，解析手順を閉じた形で 導くことができた。

本論文ではこの解析手順の詳細検討に基づき，この 手法が仅想木構造の切断点に作用する力を解析的に求 め,アクチュエータで駆動される能動対偶の作用力を 切断点での力の線形関数として表すことであることを 明らかにする。さらに多自由度対偶への対応，運動方 程式導出の詳細手順を示し，本手法が計算機プログラ ム化に適したものであることを示す。

\section{2. 解析手順}

機構の変位解析結果は既知であるとする。すなわち すべてのリンク，対偶の位置・姿勢は数值的に計算さ れているものとする．対偶軸の位置と方向から，その 対偶を構成している対偶素の相対運動を表すモータ $M$ (以後対偶モータと呼ぶ.) が計算できる.たとえば対 偶軸の方向余弦べクトルが $a$, 軸上の 1 つの点の位置べ 
クトルがrであるとき，対偶モー夕は

$$
M=\left\{\begin{array}{l}
{\left[\begin{array}{c}
a \\
r \times a
\end{array}\right]: \text { 回り対偶 }} \\
{\left[\begin{array}{l}
0 \\
a
\end{array}\right]: \text { 進み対偶 }}
\end{array}\right.
$$

である。

対偶が $f$ 自由度のときは $f$ 個の 1 自由度の対偶の直列 連結でモデル化し，f個の対偶モー夕を定める。さら にリンクの質量及び慣性テンソルを表す $6 \times 6$ 行列の慣 性バイナ $B$ オンクの位置・姿勢から計算できる。1自 由度対偶でモデル化された機構の対偶 $j$ の対偶モータ を $M_{j}$ で表すことにする.リンク $i の$ 慣性バイナを $B_{i}$ と 表す.

機構の全ての対偶素間の相対変位（以後対偶変位と 呼ぶ. 対偶速度，加速度も同様である。) を日で表す。リ ンクiの速度および加速度を表すモータをそれぞれ $V_{i}$ ， $\boldsymbol{A}_{i}$ とすると, 静止リンクからリンクiにつながる開ルー プ連鎖に付録に示す開ループ機構の関係式を用いるこ とにより,

$$
\begin{aligned}
& \boldsymbol{V}_{i}=J_{i} \dot{\boldsymbol{\theta}} \\
& \boldsymbol{A}_{i}=J_{i} \ddot{\boldsymbol{\theta}}+\dot{\boldsymbol{\theta}}^{T} P \dot{\boldsymbol{\theta}}
\end{aligned}
$$

と表すことができる。ここに，付録に示すように，Ji $m$ 個のモータを列べクトルとして持つ行列である。ま たPはその要素がモータである行列である。これによ りリンク $i$ に作用する動的力 $D_{i}$ は

$$
\boldsymbol{D}_{i}=-B_{i} \boldsymbol{A}_{i}-\boldsymbol{V}_{i} \times B_{i} \boldsymbol{V}_{i}
$$

となる

一方, 能動対偶の変位だけからなるべクトルを的と すると，対偶速度は能動対偶の速度の線形関数であり， 加速度は能動対偶の加速度の線形結合と対偶速度の 2 次形式を要素とするべクトルの和であるから，付録に 示すように

$$
\begin{aligned}
& \dot{\boldsymbol{\theta}}=C \dot{\boldsymbol{\theta}}_{a} \\
& \ddot{\boldsymbol{\theta}}=C \ddot{\boldsymbol{\theta}}_{a}+\boldsymbol{d}
\end{aligned}
$$

の形で表すことができる。ここにCは行列であり，dは 能動対偶の対偶速度の 2 次形式を要素とするベクトル である。

以上の関係を整理することにより,リンク $i$ に作用す る動的力 $D_{i}$ は

$$
\boldsymbol{D}_{i}=-G_{i} \ddot{\boldsymbol{\theta}}_{a}-\boldsymbol{Q}_{\boldsymbol{i}}
$$

の形となる。ここに $\boldsymbol{Q}_{i}$ は速度モータと運動量モ一夕の 外積項からなるモータで,

$$
\boldsymbol{Q}_{i}=B_{i} J_{i} \boldsymbol{d}+B_{i}\left(C \dot{\boldsymbol{\theta}}_{a}\right)^{T} P\left(C \dot{\boldsymbol{\theta}}_{a}\right)+\boldsymbol{V}_{i} \times B_{i} \boldsymbol{V}_{\boldsymbol{i}}
$$

で, リンク $i$ に作用する遠心力やコリオリカを表してい

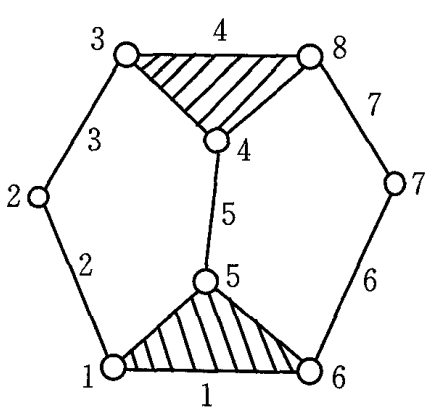

Fig.1 Closed Loop Mechanism

る。また

$$
G_{i}=B_{i} J_{i} C
$$

である。

機構のリンクでの力の釣り合い式を定めるため，機 棈の結合行列を用いる. 結合行列とはグラフの辺と頂 点の関係を示すものであるが,ここではリンクに作用 する方向を示すため, 結合行列の要素の正負を考える。 結合行列の行をリンクに, 列を対偶に対応させる，結

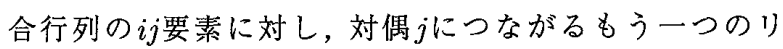

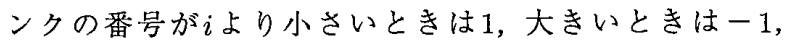
リンク $i$ に対偶 $j$ が接続していないときは 0 とする.図 1 の機構では結合行列 $\Phi$ は

$$
\Phi=\left[\begin{array}{cccccccc}
-1 & 0 & 0 & 0 & -1 & -1 & 0 & 0 \\
1 & -1 & 0 & 0 & 0 & 0 & 0 & 0 \\
0 & 1 & -1 & 0 & 0 & 0 & 0 & 0 \\
0 & 0 & 1 & -1 & 0 & 0 & 0 & -1 \\
0 & 0 & 0 & 1 & 1 & 0 & 0 & 0 \\
0 & 0 & 0 & 0 & 0 & 1 & -1 & 0 \\
0 & 0 & 0 & 0 & 0 & 0 & 1 & 1
\end{array}\right]
$$

となる。

このように結合行列を定めると, リンクiの力の釣 り合い式は, 結合行列の $i$ 行目の行べクトル $\mu_{i}$ を用いて

$$
\boldsymbol{\mu}_{i} \boldsymbol{h}+\boldsymbol{D}_{i}+\boldsymbol{F}_{i}=\mathbf{o}
$$

と書くことができる。ここに，hは対偶 $i$ 介して隣の リンクから作用する力 (对偶力) $\boldsymbol{H}_{i}$ を要素として持つべ クトル

$$
h=\left[\begin{array}{llll}
H_{1} & H_{2} & \cdots & H_{8}
\end{array}\right]^{T}
$$

であり， $\boldsymbol{F}_{i}$ はリンクiに作用する重力等の外力である. たとえばリンク 4 での鈞り合い式は

$$
\boldsymbol{H}_{3}-\boldsymbol{H}_{4}-\boldsymbol{H}_{8}+\boldsymbol{D}_{4}+\boldsymbol{F}_{4}=\mathbf{o}
$$

となる。

リンク数 $n$, 対偶数 $m$ からなる一般の閉ループ機構 について, 式(12)を静止リンクを除くすべてのリンク についてまとめて書くと，

$$
\Psi \boldsymbol{h}+\boldsymbol{e}+\boldsymbol{f}=\mathbf{0}
$$

と書ける。ここにe抢よびfはそれぞれリンクの動的力， 
外力を表す $n-1$ 個のモー夕を要素とする列べクトルで

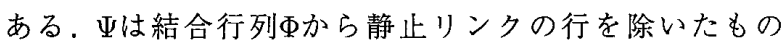
である。ここでhを，能動対偶の対偶力を全て含む $n-1$ 個の対偶力を要素を持つベクトルaと, 残りの対偶力 を要素とするpに分けると，式(14)は

$$
A \boldsymbol{a}+L \boldsymbol{p}+\boldsymbol{e}+\boldsymbol{f}=\mathbf{o}
$$

と書ける。ここに行列 $A$ は $(n-1) \times(n-1)$ の正方行列, $p$ は $n-1$ 個の対偶力を要素とする列べクトル，Lは $(n-$ 1) $\times(m+1-n)$ 行列である. 行列 $A$ が正則であるなら，

$$
\boldsymbol{a}=-A^{-1}(L \boldsymbol{p}+\boldsymbol{e}+\boldsymbol{f})
$$

を得る。

式(16)はaの要素である対偶力を与える式である。ま ず対偶が全て1自由度であるとする，aに含まれる受動 対偶の式を用いて, 受動対偶の対偶力と仮想変位との 仮想仕事が零であるという条件，すなわち，対偶力と対 偶モー夕との仮想仕事が零であると条件から, $n-1-f$ 個の条件式を得る。なお仮想仕事は対偶力と対偶モー 夕の双線形形式である相反積で与えられる。ここにfは 能動対偶の数，すなわち機構の自由度である。さらにp の要素は全て受動対偶の対偶力であり，おのおのの対 偶モー夕との相反積が零であるという条件から $m+1-n$ 個の条件式を得る。したがって，あわせて $m-f$ 個の条 件式が得られるが，これは する線形方程式である。未知数の数は $d(m+1-n)$ であ る.ここにdは機構の運動空間の次元であり，たとえば 平面機構のときは 3 , 空間機構のときは6である。

機構の自由度の式

$$
f=d(n-1)-(d-1) m
$$

が成立すると，

$$
d(m+1-n)=m-f
$$

となり，未知数と式の数が一致し，これを解くことに より，pが定まる，p用いて，式(16)から，能動対偶の 対偶力を計算し，能動対偶の対偶モータの相反積から， 入力トルクを求める.

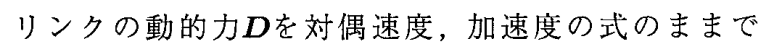
上記の計算を行えば運動方程式が導かれ，対偶の速度， 加速度から動的力を計算し，上記計算につなげると，機 構を運動させるのに必要な入力トルクが計算できる。 入力トルクの計算では，上記計算過程はすべて数值計 算であるので，一本道で計算できるが，運動方程式の 導出には, 動的力が対偶加速度および速度の関数であ り, 計算過程は数式処理となるので取り扱いが複雑と なる。この詳細については後の章で述べる。

\section{3. 行列正則化の条件}

第 2 章の計算を行うためには行列 $A$ が正則であること が必要十分条件である。このための条件の検討を行う.

行列 $A$ は機構の結合行列の幾つかの列ベクトルで構 成される。結合行列の列ベクトルは対偶がどのリンク を結合しているかを示しており，その列ベクトルは1つ の 1 と 1 つ-1を持ち，他の要素はすべて0である。い まこの結合行列から静止リンクの行を除いたものを考 える。このとき, 静止リンクに結合している列べクト ルは，1つの1かー1だけを持つ。いま行列 $A$ に静止リン クに結合している対偶が含まれないとすると，全ての 列ベクトルは 1 と-1を持ち, したがって, 行列 $A$ の行べ クトルの全ての和をとると，零べクトルとなる．した がってこのとき行列 $A$ は正則ではない。このように行 列 $A$ は少なくとも1つの静止リンクに結合する対偶を 含まなければならない.

このとき静止リンクに結合する対偶の列ベクトル

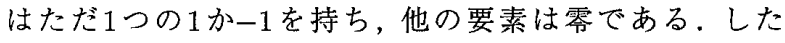
がって行列式 $|A|$ は,この対偶ベクトルで展開でき， 新たな行列式 $\left|A_{1}\right|$ を得る。行列 $A_{1}$ の列べクトルにも， ただ1つの1かー1を持つものがなければならない。でな ければ行列式 $\left|A_{1}\right|$ が零となり，行列 $A$ は正則でなくな

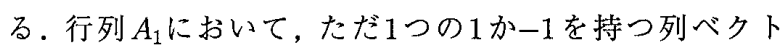
ルは, 静止リンクに結合している対偶か, あるいは行 列 $A_{1}$ を作るために取り去った対偶により静止リンクに 結合されているリンクにある対偶でなければならない。

すなわち，行列 $A_{1}$ には静止リンクから行列の中にあ る対偶により静止リンクに結合されているリンクの対 偶が少なくとも1つはなければならない. 行列式 $\left|A_{1}\right|$ はまたこの対偶べクトルで展開され, その結果得られ る行列 $A_{2}$ についても同じ議論が成立する。この過程を 最後まで続けると, 結局行列 $A$ の対偶はすべて, その 中の対偶をたどって静止リンクにたどり着けるもので なければならない.すなわち,すべてのリンク, 対偶は 連結されていなければならないことが分かる。

行列 $A$ に静止リンクを加えた機構は, リンク数が $n$ で，対偶数がn-1である。この中の対偶がすべてリン クで静止リンクに結合されているとすると，これは 1 つの機構であり, その機構のループ数ははグラフ理論の オイラーの定理より

$$
\alpha=(n-1)-n+1=0
$$

となり，したがって，機構は木構造を持つ.ゆえに行列 $A$ の対偶は元の機構の部分である木棈造の機構に属す るものでなければならない.

行列 $A$ に入らない対偶の数は $m-n+1$ で,これはルー プの数に等しい.したがって行列 $A$ に入らない対偶は 
機構のループを切断する必要最小限の対偶である. ところで行列式| $A \mid$ の值は上記操作を続けること により求まるが，展開できる数值が1かー1であるから， その值も1か-1である. 行列 $A$ の余因子についても同 じことがいえ，この場合，正則である必要はないから， その值は $1,-1$, あるいは0である。したがって行列 $A$ の 逆行列の要素も $1,-1$, あるいは0であり, これは行列 $a$ 要素であるモー夕は, $P p, e, f$ 要素であるモー 夕の加減算のみで求まることを示している。これは木 構造の機構の対偶力がリンクに作用する力の加減算で 定まることと同じ意味である。

\section{4. 多自由度対偶の取り扱い}

機構が多自由度対偶を持っている場合, その運動学 的モデルは1自由度対偶モデルで表されるが, 動力学 モデルは，1自由度対偶モデルを用いると，質量零のリ ンクを仮想しなければいけなくなり, 多自由度対偶は 多自由度対偶のままで扱った方が有利である。この場 合も上記と同様に動力学解析が行える. 多自由度対偶 の場合, その対偶の仮想仕事の条件式は対偶の自由度 と同じ数だ導かれる。 $e$ 自由度の多自由度対偶なら, その運動を表す $e$ 個の対偶モー夕を決定できる．対偶 に作用する対偶力と対偶モータとの相反積をとること により,力モータの要素を未知数とする $e$ 個の線形同次 方程式が得られる。

すべて 1 自由度の対偶からなる機構の, たとえば $e$ 個 の対偶を $e$ 自由度の多自由度機構に置き換えた場合を 考える.このとき機構の対偶素数及びリンクの数が減 少する.1自由度の対偶である機構が

- 機構の自由度: $f$, リンク数: $n$, 対偶数: $m$ であったとすると, 多自由度対偶に置き換えた機構では

- 機構の自由度: $f$, リク数: $n+1-e$, 対偶数: $m+1-e$ となり,ループ数は同じ $m+1-n$ である. 動力学解析式 で, $\boldsymbol{p}$ の要素である対偶の数はループ数と同じである. したがって，aに含まれる受動対偶の数は 1 自由度対偶 からなる機構の場合は $n-1-f$, 多自由度対偶に置き 換えた機構では $n-e-f て ゙ あ る 。$ 求めなければいけない 力は $\boldsymbol{p}$ の要素で,これは両者同じく $d(m+1-n)$ でり， 前者の場合は仮想仕事の条件から導かれる式の数も同 じであることを前章で示した．後者の機構では，対偶 の数は $e-1$ 個減るが, 仮想仕事の条件式が, 多自由度 機構で $e-1$ 個增えるため, 条件式の数は変わらず, $p$ の 要素の值が決定できることがわかる。これは多自由度 対偶が $a, p$ い゙れに含まれていても同じである。

同じ議論が複数個の多自由度対偶を持つ機構にも当
てはまり，したがって，機構が多自由度対偶を持ってい ても，前章で示した手法で動力学解析が行える.

以上のように機構が多自由度対偶も持っていてもい なくても, 仮想仕事の条件式は同じ数, すなわち機構 の運動空間の次元数とループ数の積となる。したがっ て,この部分の計算負荷はほぼ同等であるが, 厳密に いうと，pに多自由度対偶が含まれている方が少し計 算量が少なくなる．p住含まれる対偶の仮想仕事の条 件式は，その対偶力の要素だけの線形式である。した がって, $\boldsymbol{b}$ の $e$ 自由度の対偶の場合, 未知数を $d-e$ 個と し, 残りの要素を $\boldsymbol{p}$ の対偶の仮想仕事の条件から未知数 の関数として定め, $\boldsymbol{a}$ の想仕事の条件からこれらの未 知数を求めるという手法をとることができる。このよ うな手法をとることにより, 次数の大きな線形方程式 を次数の少ない複数の線形方程式に分解できる．pに 多自由度対偶が含まれる方がこの分解をより細かくで きる。

また多自由度対偶を持つ機構の方がリンク数が少な くなるため, 動的力の計算については有利である。

\section{5. 運動方程式導出のための数式処理}

式(7)における行列 $G_{i}$ で， $B_{i}$ および $J_{i}$ は，リンクの慣 性テンソル, 質量, 対偶モータで值が決まるもので, 動 力学解析においては数值として扱われる。Cは機構の 対偶の速度と能動対偶の速度との関係を表す行列で, 機構の形式によって定まるものである..

一方 $\boldsymbol{Q}_{i}$ は能動対偶の速度の 2 次形式であり，その係数 は同じくリンクの慣性テンソル, 質量, 対偶モー夕で 決まるもので，その数值は運動解析により計算できる ものである。

したがって運動方程式導出過程では

$$
\boldsymbol{D}_{i}=-G_{i} \ddot{\boldsymbol{\theta}}_{a}-\dot{\boldsymbol{\theta}}_{\boldsymbol{a}}^{T} Q_{i} \dot{\boldsymbol{\theta}}_{a}
$$

の形に書ける。ここに $G_{i}, Q_{i}$ の要素はモータであり, これらの值は数值として既知である。

式(16)のaから, 受動対偶(対偶番号 $j$ )の1行だけを取 り出すと,これは, $p$ の要素の受動対偶の力モー夕の 線形結合と, 能動対偶の加速度の線形式を要素とする モ一夕項と, 能動対偶の速度の2次形式を要素とする モータ項 $U_{j}$, およびリンクに作用する外力 $\boldsymbol{F}$ の和の項 $\boldsymbol{K}_{j}$ であり，

$$
\boldsymbol{H}_{j}=s^{T} \boldsymbol{p}+S \ddot{\boldsymbol{\theta}}_{a}+\boldsymbol{U}_{j}+\boldsymbol{K}_{j}
$$

の形となる.

ところで $\boldsymbol{p}$ の要素である受動対偶の対偶力を

$$
\boldsymbol{H}=\left[\begin{array}{llll}
x_{1} & x_{2} & \cdots & x_{6}
\end{array}\right]^{T}
$$

とする．1自由度対偶であるなら，仮想仕事が零という 
条件から

$$
\lambda_{1} x_{1}+\lambda_{2} x_{2}+\cdots+\lambda_{6} x_{6}=0
$$

の既知の係数 $\lambda$ を持つ $1 つ の$ 線形同次式が成立するとい うことである。ここに入は対偶モータの要素である。こ れから, 对偶力は

$$
\boldsymbol{H}=\left[\begin{array}{ccccc}
1 & 0 & 0 & 0 & 0 \\
0 & 1 & 0 & 0 & 0 \\
0 & 0 & 1 & 0 & 0 \\
0 & 0 & 0 & 1 & 0 \\
0 & 0 & 0 & 0 & 1 \\
-\frac{\lambda_{1}}{\lambda_{6}} & -\frac{\lambda_{2}}{\lambda_{6}} & -\frac{\lambda_{3}}{\lambda_{6}} & -\frac{\lambda_{4}}{\lambda_{6}} & -\frac{\lambda_{5}}{\lambda_{6}}
\end{array}\right]\left[\begin{array}{l}
x_{1} \\
x_{2} \\
x_{3} \\
x_{4} \\
x_{5}
\end{array}\right]
$$

と末知数 $5 つ を$ 要素とする 5 次元べクトルの線形式で表 される．同様に $e$ 自由度の対偶力は $6-e$ 個の未知数を 要素とするべクトルの線形式で表される。このように $p$ の要素を未知数の線形式で表すと, $s^{T} p$ も同じく全て の未知数の線形式となり, 未知数を要素とするべクト ルを $\boldsymbol{x}$ すると，

$$
s^{T} \boldsymbol{p}=W \boldsymbol{x}
$$

と書ける。ここにWはその要素がすべて既知である行 列である。

$$
\begin{aligned}
& \text { 式 }(21) \text { と対偶モー夕の相反積は } \\
& \boldsymbol{M}_{j} \circ \boldsymbol{H}_{j} \\
&=\left(T \boldsymbol{M}_{j}\right)^{T} \boldsymbol{H}_{j} \\
&=\left(T \boldsymbol{M}_{j}\right)^{T} W \boldsymbol{x}+\left(T \boldsymbol{M}_{j}\right)^{T} S \ddot{\boldsymbol{\theta}}_{a} \\
&+\left(T \boldsymbol{M}_{j}\right)^{T} \boldsymbol{Q}_{j}+\left(T \boldsymbol{M}_{j}\right)^{T} \boldsymbol{K}_{j} \\
&= 0
\end{aligned}
$$

となる。ここに行列 $T$ は

$$
T=\left[\begin{array}{cc}
0 & E_{3} \\
E_{3} & 0
\end{array}\right] \text { たたし }: E_{3}: 3 \times 3 \text { 単位行列 }
$$

である.式(26)第 2 行の左辺の第 1 項は未知数 $x$ の線形 形式，第 2 項は能動対偶の加速度の線形形式，第 3 項は 能動対偶の速度の積, すなわち $\theta_{a i} \theta_{a j}$ の線形形式, 外力 の項は定数であるから，結局式(26)は

$$
\boldsymbol{k}^{T} \boldsymbol{x}=\boldsymbol{l}^{T} \ddot{\boldsymbol{\theta}}_{a}+\boldsymbol{m}^{T} \boldsymbol{q}+\beta
$$

の形となる．ここで，qは能動対偶の速度の積の項であ $\eta, k, l, m$ は既知の值を持つベクトル, $\beta$ は既知のス カラである。

式(28)の関係が， $a$ の受動対偶の要素すべてに成り立 つから、これらをまとめると，

$$
K \boldsymbol{x}=L \ddot{\boldsymbol{\theta}}_{a}+M \boldsymbol{q}+\boldsymbol{\beta}
$$

となる，行列 $K$ は正方行列であり， $\boldsymbol{x}$ は式(29)の雨辺に

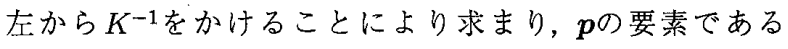
対偶力は $\boldsymbol{x}$ の線形関数であるから, 式(25)の左から行列 を掛けると求まる，aの要素である能動対偶の対偶力 は式(16)の右辺にこの結果である $\boldsymbol{p}$ を代入すればよい. これと能動対偶の対偶モータの相反積をとると運動方
程式となる。

このように, 本手法を用いると, 運動方程式導出過 程を計算機処理に適した行列計算で記述でき，また従 来のようなラグランジュ乗数等の新たなパラメータを 導入する必要がなく, 従来の手法に比べ, 計算負荷を 少なくすることが期待できる。

\section{6. 計算例}

図 1 機構が平面機構で, 対偶がすべて 1 自由度対偶 なら，機構の自由度は2である。この機構の能動対偶を 対偶 1 と6とした場合の動的力の解析を行う。この機構 の結合行列は式(10)であり，1行目は静止リンクのリン ク 1 に対応するものである. 能動対偶は 1 と6である. $p$ に属する対偶の力モータを対偶 2 と対偶 8 とすると，

$$
P=\left[\begin{array}{cc}
-1 & 0 \\
1 & 0 \\
0 & -1 \\
0 & 0 \\
0 & 0 \\
0 & 1
\end{array}\right]
$$

であり

$$
A=\left[\begin{array}{cccccc}
1 & 0 & 0 & 0 & 0 & 0 \\
0 & -1 & 0 & 0 & 0 & 0 \\
0 & 1 & -1 & 0 & 0 & 0 \\
0 & 0 & 1 & 1 & 0 & 0 \\
0 & 0 & 0 & 0 & 1 & -1 \\
0 & 0 & 0 & 0 & 0 & 1
\end{array}\right]
$$

である。

この行列 $A$ の逆行列は

$$
A^{-1}=\left[\begin{array}{cccccc}
1 & 0 & 0 & 0 & 0 & 0 \\
0 & -1 & 0 & 0 & 0 & 0 \\
0 & -1 & -1 & 0 & 0 & 0 \\
0 & 1 & 1 & 1 & 0 & 0 \\
0 & 0 & 0 & 0 & 1 & 1 \\
0 & 0 & 0 & 0 & 0 & 1
\end{array}\right]
$$

となる。このように行列 $A$ は正則であるが，たとえば $P の 1$ 列目と $A$ の 6 列目を入れ替えると，Aの6行目の行 ベクトルが零になり，これは同じループ内にある対偶 7 と 8 のモータをpにしたことに対応する。

式(32)を用いると、式(16)は

$$
\left[\begin{array}{l}
\boldsymbol{H}_{1} \\
\boldsymbol{H}_{3} \\
\boldsymbol{H}_{4} \\
\boldsymbol{H}_{5} \\
\boldsymbol{H}_{6} \\
\boldsymbol{H}_{7}
\end{array}\right]=\left[\begin{array}{cc}
1 & 0 \\
1 & 0 \\
1 & -1 \\
-1 & 1 \\
0 & -1 \\
0 & -1
\end{array}\right]\left[\begin{array}{l}
\boldsymbol{H}_{2} \\
\boldsymbol{H}_{8}
\end{array}\right]
$$




$$
-\left[\begin{array}{c}
\boldsymbol{R}_{2} \\
-\boldsymbol{R}_{3} \\
-\boldsymbol{R}_{3}-\boldsymbol{R}_{4} \\
\boldsymbol{R}_{3}+\boldsymbol{R}_{4}+\boldsymbol{R}_{5} \\
\boldsymbol{R}_{6}+\boldsymbol{R}_{7} \\
\boldsymbol{R}_{7}
\end{array}\right]
$$

となる。ただしここでは $\boldsymbol{R}_{i}$ はリンクにに作用する動的力 と外力の和であるとする。

式(33)から，受動対偶である $3 ， 4 ， 5 ， 7$ に対応する行 を抜き出し，その下に $\boldsymbol{H}_{2}$ と $\boldsymbol{H}_{8}$ の等式を加えると，

$$
\begin{aligned}
{\left[\begin{array}{l}
\boldsymbol{H}_{3} \\
\boldsymbol{H}_{4} \\
\boldsymbol{H}_{5} \\
\boldsymbol{H}_{7} \\
\boldsymbol{H}_{2} \\
\boldsymbol{H}_{8}
\end{array}\right]=} & {\left[\begin{array}{cc}
1 & 0 \\
1 & -1 \\
-1 & 1 \\
0 & -1 \\
1 & 0 \\
0 & 1
\end{array}\right]\left[\begin{array}{l}
\boldsymbol{H}_{2} \\
\boldsymbol{H}_{8}
\end{array}\right] } \\
& -\left[\begin{array}{c}
-\boldsymbol{R}_{3} \\
-\boldsymbol{R}_{3}-\boldsymbol{R}_{4} \\
\boldsymbol{R}_{3}+\boldsymbol{R}_{4}+\boldsymbol{R}_{5} \\
\boldsymbol{R}_{7} \\
\mathbf{0} \\
\mathbf{0}
\end{array}\right]
\end{aligned}
$$

を得る。

式(34)の両辺の左側から, 対角成分が $\left(T M_{3}\right)^{T},\left(T M_{4}\right)^{T}$, $\left(T M_{5}\right)^{T},\left(T M_{7}\right)^{T},\left(T M_{2}\right)^{T},\left(T \boldsymbol{H}_{8}\right)^{T}$ で, 残りの要素が $\mathbf{0}^{T}$ である行列をかけると, 受動対偶に作用する力モー 夕による仮想仕事が零であるという条件式が得られる。 これを実際に計算すると

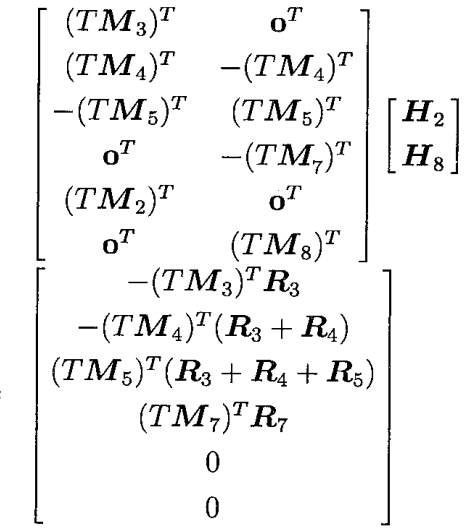

を得る。

この機構は平面機構であり，モー夕は3次元である から, 式(35)の最初の行列は, 要素をスカラで表すと $6 \times 6$ 行列となる。この逆行列を式(35)両辺に左からか けると， $\boldsymbol{H}_{2}$ および $\boldsymbol{H}_{8}$ の值が定まる。この值を式(33)の 能動対偶 1,6 に対応する行を抜き出した式

$$
\left[\begin{array}{l}
\boldsymbol{H}_{1} \\
\boldsymbol{H}_{6}
\end{array}\right]=\left[\begin{array}{cc}
1 & 0 \\
0 & -1
\end{array}\right]\left[\begin{array}{l}
\boldsymbol{H}_{2} \\
\boldsymbol{H}_{8}
\end{array}\right]-\left[\begin{array}{c}
\boldsymbol{R}_{2} \\
\boldsymbol{R}_{6}+\boldsymbol{R}_{7}
\end{array}\right]
$$

に代入すれば，能動刘偶に作用する力モータが定まる。 これらのカモータと対偶モータとの相反積が以下のよ
うに機構の運動により能動対偶に作用するトルクを与 える。

$$
\begin{aligned}
\boldsymbol{\tau}= & {\left[\begin{array}{l}
\tau_{1} \\
\tau_{6}
\end{array}\right] } \\
= & {\left[\begin{array}{cc}
\left(T \boldsymbol{M}_{1}\right)^{T} & \mathbf{o}^{T} \\
\mathbf{o}^{T} & \left(T \boldsymbol{M}_{6}\right)^{T}
\end{array}\right] } \\
& \left(\left[\begin{array}{cc}
1 & 0 \\
0 & -1
\end{array}\right]\left[\begin{array}{c}
\boldsymbol{H}_{2} \\
\boldsymbol{H}_{8}
\end{array}\right]-\left[\begin{array}{c}
\boldsymbol{R}_{2} \\
\boldsymbol{R}_{6}+\boldsymbol{R}_{7}
\end{array}\right]\right)
\end{aligned}
$$

力の解析のときは， $R$ 值は既知であるので，その 值を式(37)に代入すれば，能動対偶のトルクが求まる。 運動方程式導出の場合，Rは第 5 章で示したように，能 動対偶の加速度ベクトルと速度積ベクトル

$$
\begin{aligned}
\ddot{\boldsymbol{\theta}}_{a} & =\left[\begin{array}{ll}
\ddot{\theta}_{1} & \ddot{\theta}_{6}
\end{array}\right]^{T} \\
\boldsymbol{q} & =\left[\begin{array}{lll}
\dot{\theta}_{1} \dot{\theta}_{6} & \dot{\theta}_{1}^{2} & \dot{\theta}_{6}^{2}
\end{array}\right]^{T}
\end{aligned}
$$

の線形形式と定数項の和を要素とするモータである。. これらの係数はすべて既知であるので，この式を式(37) に代入することにより運動方程式が求まる。

\section{7. まとめ}

本論文ではモータ(スクリュー座標)を用いた閉ルー プ機構動力学解析の計算手順の導出を行った。運動お よび力をモータで表すことにより，線形計算で解析が でき，したがって，式の展開を計算機処理に適した行列 表現で書き下すことができた．本論文で導いた方式は， 基本的にはループ切断法と同じであることを，行列の 正則の条件から導いた。しかし従来のループ切断法で 用いていたラグランジュ乗数や，切断点に打ける仮想 の力等の余分なパラメータを設定することなしに，切 断点の力を計算する式を系統だって導くことができた。 これらの特徵により, 計算負荷の少ない計算機プログ ラム開発に寄与し得るものである.

\section{文献}

(1)中村, 日本ロボット学会誌, Vol.10, No.6, 1992, pp.709-714. (2)J.Y.S Luh and Y. Zheng, IEEE, J. of Robotics and Automation, Vol.RA-1, 1985, pp.95-103.

(3) 遠山, 渡部, 田野, 日本ロボット学会, Vol.14, No.2, 1996, pp.279286

(4)K. Sugimoto, Trans. ASME, J. of MTAD,Vol.111, March 1989, pp.29-33.

(5)杉本, 原, 增田, 日本ロボット学会, Vol.7, No. 6, 1989, pp.685693.

(6)杉本, 日本ロボット学会誌, Vol.15, No.3, 1997, pp.460-467.

\section{付 録}

まず開ループ機構の速度, 加速度の関係式を示す. $p$ 個の対偶により $p+1$ 個のリンクが直列に結合され た開ループ連鎖を考える。リンクには静止リンクを0 とし，1，2，3，‥と順に番号を付け，対偶にはリンク 
0 側から $1,2,3, \ldots$ と番号を付ける.リンク $i$ 速度を モータ $\boldsymbol{V}_{i}$ で表わす。リンクiの速度は対偶 1 から $i$ まで の相対速度の和であるから

$$
V_{i}=\dot{\theta}_{1} M_{1}+\dot{\theta}_{2} M_{2}+\ldots+\dot{\theta}_{i} M_{i}
$$

である。

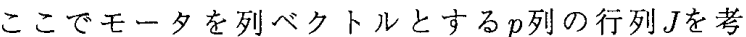
えリンク $i$ に対する行列を

$$
J_{i}=\left[\begin{array}{lllllll}
M_{1} & M_{2} & \ldots & M_{i} & \mathbf{o} & \ldots & \mathbf{o}
\end{array}\right]
$$

とする。また対偶変位べクトル $\boldsymbol{\theta}$ を $\left[\begin{array}{llll}\theta_{1} & \theta_{2} & \ldots & \theta_{p}\end{array}\right]^{T}$ とす ると, 式(39)は

$$
\boldsymbol{V}_{i}=J_{i} \dot{\theta}
$$

と表される。

リンク $i$ 速度を表す式(39)を時間 $t$ で微分すると,

$$
\begin{aligned}
\boldsymbol{A}_{i}= & \frac{d}{d t} \boldsymbol{V}_{i} \\
= & \boldsymbol{A}_{i-1}+\ddot{\theta}_{i} \boldsymbol{M}_{i}+\boldsymbol{V}_{i-1} \times\left(\dot{\theta}_{i} \boldsymbol{M}_{i}\right) \\
= & \ddot{\theta}_{1} \boldsymbol{M}_{1}+\ddot{\theta}_{2} \boldsymbol{M}_{2}+\ldots+\ddot{\theta}_{i} \boldsymbol{M}_{i}+ \\
& \dot{\theta}_{1} \boldsymbol{M}_{1} \times\left(\dot{\theta}_{2} \boldsymbol{M}_{2}\right)+ \\
& \left(\dot{\theta}_{1} \boldsymbol{M}_{1}+\dot{\theta}_{2} \boldsymbol{M}_{2}\right) \times\left(\dot{\theta}_{3} \boldsymbol{M}_{3}\right)+\ldots+ \\
& \left(\dot{\theta}_{1} \boldsymbol{M}_{1}+\ldots+\dot{\theta}_{(i-1)} \boldsymbol{M}_{i-1}\right) \times\left(\dot{\theta}_{i} \boldsymbol{M}_{i}\right)
\end{aligned}
$$

を得る。これがリンクiの加速度モー夕 $\boldsymbol{A}_{i}$ を元る。ま たこれは

$$
\boldsymbol{A}_{i}=J_{i} \ddot{\boldsymbol{\theta}}+\dot{\boldsymbol{\theta}}^{T} P_{i} \dot{\boldsymbol{\theta}}
$$

と書くこともできる。ここに $P$ は $m$ 行 $n$ 列要素 $\boldsymbol{P}_{m n}$ がモ

ータである $p \times p$ 行列であり

$$
P=\left[\boldsymbol{P}_{m n}\right]
$$

ただし

である。

$$
\boldsymbol{P}_{m n}=\left\{\begin{array}{cl}
M_{n} \times M_{m} & \mathrm{n}<\mathrm{m}<\mathrm{i} \text { } の と き ~ \\
\mathbf{o} & \text { それ以外 }
\end{array}\right.
$$

ついで $m$ 個の対偶から成る単ループ機構の運動方程 式を求める手順を示す。なお対偶は 1 から $m$ に順に番号 が付けられているものとする

$$
\begin{gathered}
\text { まずループ内での速度の釣り合い式は } \\
\dot{\theta}_{1} M_{1}+\dot{\theta}_{2} M_{2}+\ldots+\dot{\theta}_{m} M_{m}=\mathbf{o}
\end{gathered}
$$

である.単ループ機構の対偶は, その幾つかがアクチュ エータで駆動される能動対偶であり, 残りが受動対偶 である，能動対偶の変位べクトルを $\boldsymbol{\theta}_{a}$, 受動対偶の変 位べクトルを的とすると, 式(45)は

$$
A \dot{\boldsymbol{\theta}}_{a}=B \dot{\boldsymbol{\theta}}_{b}
$$

と書ける. 空間単ループ機構の場合ベクトル $\dot{\boldsymbol{\theta}}_{b}$ の次元 は6で, 行列 $B$ は $6 \times 6$ 行列である。一般にはベクトル $\dot{\boldsymbol{\theta}}_{b}$ の次元と行列 $B$ のランクは等しく, これらは機構の対 偶モー夕の張る線形空間の次元と等しい.したがって， 線形空問の基底の座標で式(46)を表すと, 行列 $B$ は常 に正方行列である。機構が特異点にいなければ，行列 Bは正則であり，したがって

$$
\dot{\boldsymbol{\theta}}_{b}=B^{-1} A \dot{\boldsymbol{\theta}}_{a}
$$

の関係から，受動対偶の速度べクトルが求まる。した がって単ループ機構の対偶ベクトルを日とすると

$$
\dot{\boldsymbol{\theta}}=\left[\begin{array}{c}
E \\
B^{-1} A
\end{array}\right] \dot{\boldsymbol{\theta}}_{a}=C \dot{\boldsymbol{\theta}}_{a}
$$

と能動対偶の対偶速度の線形関数として表すことが できる。ここにEは単位行列である。

一方加速度の釣り合い式は

$$
\begin{aligned}
& \ddot{\theta}_{1} M_{1}+\ddot{\theta}_{2} M_{2}+\ldots+\ddot{\theta}_{m} M_{m}+ \\
& \dot{\theta}_{1} M_{1} \times \dot{\theta}_{2} M_{2}+\left(\dot{\theta}_{1} M_{1}+\dot{\theta}_{2} M_{2}\right) \times \dot{\theta}_{3} M_{3}+ \\
& \left(\dot{\theta}_{1} M_{1}+\dot{\theta}_{2} M_{2}+\ldots+\dot{\theta}_{m-1} M_{m-1}\right) \\
& \quad \times \dot{\theta}_{m} M_{m}=\mathbf{o}
\end{aligned}
$$

である。ここで対偶モータの外積の項をループの速度 外積和と呼び, $S て ゙$ 表す. 速度外積和 $\boldsymbol{S} \dot{\boldsymbol{\theta}}$ の 2 次形式で あるが, $\dot{\boldsymbol{\theta}}$ は自品の線形関数であるから, 能動対偶の対偶 速度である $\dot{\theta}_{a}$ の 2 次形式である。この式から速度のとき と同様に

$$
A \ddot{\boldsymbol{\theta}}_{a}+\boldsymbol{S}=B \ddot{\boldsymbol{\theta}}_{b}
$$

となり

$$
\begin{aligned}
\ddot{\boldsymbol{\theta}} & =\left[\begin{array}{c}
E \\
B^{-1} A
\end{array}\right] \ddot{\boldsymbol{\theta}}_{a}+\left[\begin{array}{c}
\mathbf{o} \\
B^{-1} \boldsymbol{S}
\end{array}\right] \\
& =C \ddot{\boldsymbol{\theta}}_{a}+\boldsymbol{d}
\end{aligned}
$$

と能動対偶の対偶速度, 対偶加速度の関数として表さ れる。ベクトルdは $m$ 次元のベクトルであり, 最初から 能動対偶と同じ数の元は零である.

閉ループ機構での速度, 加速度については, そのルー プ毎に単ループ機構と同じ関係式が得られる。機構の 全てのループについての関係式を，機構全体について まとめると，

$$
\begin{aligned}
L \Phi \dot{\boldsymbol{\theta}} & =0 \\
L \Phi \ddot{\boldsymbol{\theta}}+\left[\begin{array}{c}
\boldsymbol{S}_{1} \\
\boldsymbol{S}_{2} \\
\vdots \\
\boldsymbol{S}_{q}
\end{array}\right] & =0
\end{aligned}
$$

が得られる。このように閉ループ機構の対偶速度, 加 速度の関係式は単ループ機構のときと同じ形で表され る。ここにqは機構のループ数である。

単ループ機構のときと同様に娄を能動対偶の $\dot{\boldsymbol{\theta}}_{a}$ と $\dot{\boldsymbol{\theta}}_{b}$ と に分けると，式(52)，(53) はそれぞれ式(46)，(50)の形に 変形できる。従って, 単ループ機構のときと同様に, 式 (52), (53)は

$$
\begin{aligned}
& \dot{\boldsymbol{\theta}}=C \dot{\boldsymbol{\theta}}_{a} \\
& \ddot{\boldsymbol{\theta}}=C \ddot{\boldsymbol{\theta}}_{a}+\boldsymbol{d}
\end{aligned}
$$

の形に書ける。 